\title{
The first Harrison Lecture, 1974 The life and times of Colonel Harrison
}

\author{
AMBROSE KING \\ Consulting Physician for Venereology, The London Hospital
}

" Let us now praise famous men, and our fathers in their generation.

..........

Leaders of the people in their deliberations

Wise in their words of instruction.

There are some of them who have left a name so that men declare their praise, and there are some who have no memorial, who have perished as though they had not lived."

Ecclesiasticus, 44, v. 1

It is said that the devil quotes scripture for his purposes, so may I be allowed to open with that quotation from the Book of Ecclesaisticus. Or, perhaps even more suitable for our purpose is the same thought adapted in the school song of Kipling's Stalky and Co.:

" 'Let us now praise famous men'-

Men of little showing-

For their work continueth,

And their work continueth,

Broad and deep continueth,

Greater than their knowing!"

The Harrison Lectures have been instituted to commemorate the work of one famous man and to ensure that he has a fitting memorial. As the first lecturer I am proud to have been allotted the task of giving you, who come after, some insight into his life and times.

Lawrence Whitaker Harrison was born in 1876 in Haslingden, in Lancashire, where his father, Jonathan Harrison, was a general practitioner and a Justice of the Peace. He was educated at Manchester Grammar School and at the University of Glasgow, where he qualified M.B., B.Ch. in 1897 . When he was a student the statutes of most hospitals forbade them to admit cases of early venereal disease and he saw only one case, a syphilitic chancre, shown sub rosa by an assistant surgeon. He tells us also that, during this time, as a full private in the Volunteer Medical Staff Corps, he saw, in a small ward in the Royal Victoria Hospital, Netley, a number of soldiers whose faces were literally rotting away with tertiary syphilis. Two years after qualification he joined the Army Medical Services and served in the South African war as a general duties Medical Officer from 1899 to 1902. In those years he was mostly with units in the field. He saw only one case of V.D., his sick corporal, who suddenly lost the bridge of his nose. He had made no complaint. I should perhaps add that the term 'sick corporal' was an accepted military designation of that period; it does not refer to that poor man's predicament. During that war Harrison was mentioned in dispatches.

On returning to England he became interested in bacteriology. In the same year (1902) he was promoted to Captain and posted to India. He recalled later ${ }^{1}$ that his interest in venereal diseases was first aroused when he was in charge of a cantonment hospital at an Indian military station. His duties there in respect of V.D. seem to have been limited to the care of some infected natives and to epidemiological work among prostitutes. The Medical Officer in charge of military patients with V.D. at Harrison's station was able to finish his round before his cigarette, deposited alight in the medical officers' room when he set out, had become extinguished. He used to boast of this accomplishment. Harrison's account of his method for the prevention of spread of V.D. at this time should be of interest to modern epidemiologists. At first he used to make examinations of the prostitutes at a few minutes notice, to prevent any preliminary cleaning up. Smears were taken from cervical canals and examined in a laboratory set up in his bungalow-there was no other in that station. If a smear was positive the patient was retained in the cantonment hospital for treatment. This method proved to be useless for preventing the infection of soldiers because the 
infectivity of women suffering from gonorrhoea was very intermittent and presumably the smears proved unreliable. He very rarely saw any woman with early signs of syphilis. A soldier infected with V.D. was asked if he could identify the source of his infection. If the latter was said to have been in the bazaar and not a casual roadside encounter, an identification parade was held. This too proved useless. Therefore, with money subscribed by British units, he rented a small room at the end of the prostitute quarter in the bazaar and arranged for the matron of the cantonment hospital to disinfect the women daily, on the assumption that all were infected-as indeed they were, intermittently. This method proved completely successful in preventing infection of soldiers in that bazaar.

He added a note which will be of interest to those concerned with health education. Nothing was said to any soldier about the precautions taken in respect of the prostitutes. There was, at that time, a travelling lecturer who included in his talk directions to soldiers for personal disinfection. This man was thoroughly unpopular with commanding officers, who had noted that the numbers of cases of V.D. almost always increased after his visits.

In 1904 Harrison was granted 6 months' leave and it was while returning to the United Kingdom in a troopship in that year that he met the lady who was to be his wife, Miss Mabel Alice Fairland, younger daughter of Colonel E. J. Fairland of the Army Medical Services. They married in March, 1905, and returned to India. At this time Harrison was much concerned with the laboratory diagnosis of malaria; but 1905 was to be a fateful year for anyone who had taken even a passing interest in the venereal diseases.

The Harrisons returned to England in 1908 and Captain Harrison was then posted to the Military Hospital at Millbank for general duties.

In 1909 a hospital of one of the Guards Regiments at Rochester Row was converted into a hospital for research and instruction in the venereal diseases. It was, in effect, an offshoot of the Millbank Hospital and the Royal Army Medical College, and was commanded by another pioneer in the subject of venereology, Colonel F. J. Lambkin. In the same year Harrison was posted to Rochester Row to take the post of pathologist which had suddenly become vacant, because of illness. He recorded the fact that he went there most unwillingly because he wanted to work at and teach bacteriology at the Royal Army Medical College. Up to that time there had been no facilities for demonstrating the Spirochaeta pallida, as it was then called, and the Wassermann Reaction was not available. One can only imagine what a stimulus this proved to a man of Harrison's outlook and temperament. Then and for a long time afterwards he had to deal with numbers of interested visitors who were anxious to see the causative organism of syphilis. In those days there were plenty of cases of infectious syphilis but, in order to have specimens of the organism always available, Harrison kept serum containing the treponemes in capillary tubes, a method which, in after years, proved to be a practical means of preserving specimens for darkground examination for transmission by post.

The discovery of Salvarsan (606. Arsphenamine) by Ehrlich and Hata in 1909 was, of course, a matter of major interest to the research group at Rochester Row. The drug became available commercially in December, 1910, but Harrison obtained a supply some months earlier. At this early stage, in 1910 and 1911 , much of the pioneer work in the use of this remedy was done by the team of which he was a member. ${ }^{4}$ The results of treatment were shown to be superior to any method which had gone before. The facilities at Rochester Row gave the opportunity for close study and follow-up of the patients which was not available elsewhere. The treatment had considerable dangers and it took time to determine the correct dosage and method of administration. Very early in the course of these studies it became clear that the use of the arsenical alone led to the danger of neuro-recurrences, mainly in the form of cranial nerve palsies. In consequence, a method of treatment, believed to have been recommended by Neisser, was adopted, in which heavy metal, at this time mercury, was given at the same time as the arsenical. The results of combined treatment were considerably more satisfactory and the method was to be used with great benefit in the 1914-1918 war. The extent to which Harrison and his colleagues were ahead of their time is illustrated by the fact that at the London Hospital the treatment of early syphilis, then conducted by eminent dermatologists, was based on arsenicals alone up to the year 1930 .

At Rochester Row research was also directed to the other venereal diseases. The extent to which they were ahead of their time was also shown by Harrison's disapproval of the use of strong antiseptic solutions for urethral irrigation and of some of the methods of irrigation which were then in general use. He maintained that solutions of potassium permanganate should be no stronger than $1: 8,000$, that irrigation should be given by gravity and not with urethral syringes, and that the container of irrigating fluid should be not more than 3 feet above the patient's pelvis. His immediate predecessor in charge of the gonorrhoea ward had other ideas and had, in fact, raised the level of irrigators to 10 feet. Practically 
every patient in the ward had developed epididymitis which was attributed to the fact that they were allowed turkey and other luxuries at Christmas. Harrison's suggestion that the vigour of treatment was responsible was received with anger and resentment. Time and experience showed how absolutely sound these ideas were. The aspiration method he adopted for the treatment of suppurating buboes is accepted procedure at the present day. Harrison worked on the Wassermann Reaction from 1910 to 1914 and the technique to which his name was given, the HarrisonWyler method, was widely used for many years afterwards.

He has told us a good deal about his experimental work during that period. One method was the treatment of gonorrhoea by the passage of bougies heated by electric current or hollow metal sounds through which hot water was made to run. The rationale was that the gonococcus was known to be susceptible to a comparatively low degree of heat. This was not original for it had been claimed as effective in Germany and India, but perhaps it was the forerunner of fever therapy on which some of us were to spend much time and trouble later. Results with the heated bougies seemed brilliant at first, as with diathermy in later years, but the method failed to stand the test of long-term assessment. Another method which he tried later in France was the use of intramuscular mercury for the treatment of gonorrhoea, based on the observation that patients treated for both syphilis and gonorrhoea seemed to do better as regards the urethritis than others. Again the immediate results seemed excellent and there were high hopes that this would prove a specific remedy. After the assessment of about 7,000 cases it was decided that nothing was gained by this treatment. It was a wise, though cynical, member of our profession who once said, 'let us hasten to use this new remedy while it still cures patients'.

Harrison was promoted to the rank of Major in 1911. Fig. 1 shows him in military uniform in 1913then, as later, a splendid figure of a man.

On the outbreak of war in 1914 Harrison was swept away from all activities concerned with V.D. to join the British Expeditionary Force in France. He seems to have regarded this as a welcome break and at this point in his career he hoped he would never again have anything to do with the subject. But circumstances were to prove too much for him.

The British Expeditionary Force went to France in 1914 with no special provision for the treatment of V.D. There was no arsenobenzol, no mercury, and not a single irrigating apparatus for the treatment of gonorrhoea. The sole anti-venereal measure was a leaflet signed by Lord Kitchener, the Secretary of

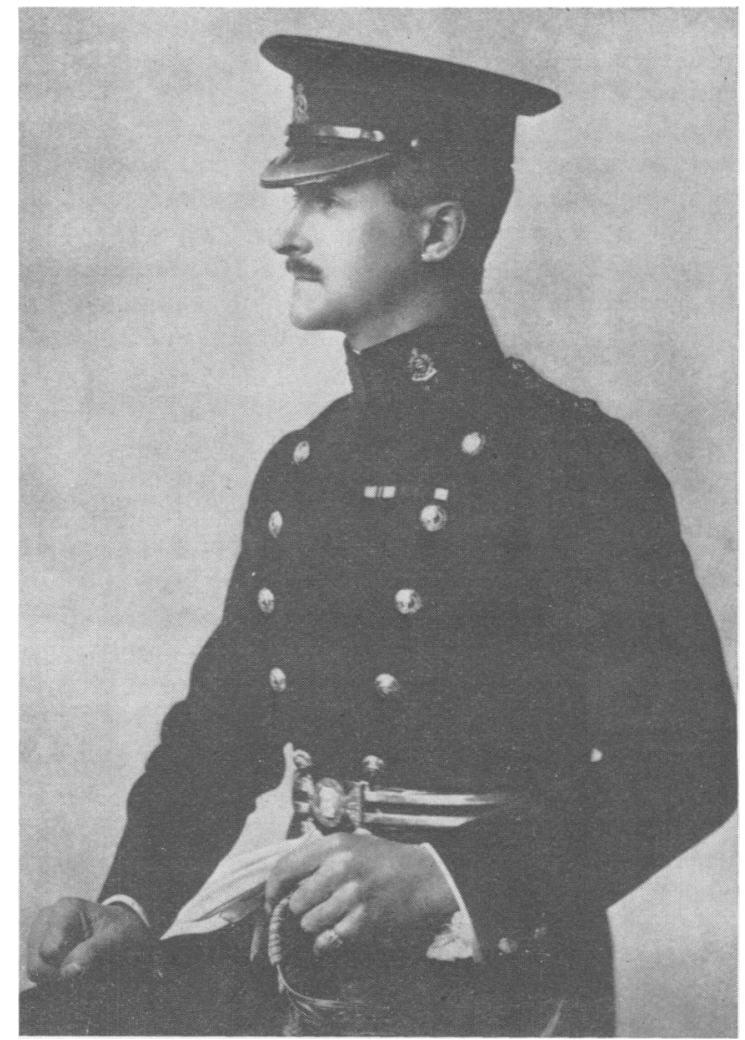

FIG. 1 Major L. W. Harrison in 1913

State for War, exhorting the troops to sexual continence. When patients with V.D. began to report at medical units, senior officers raved about unpatriotic conduct and some advocated letting the adjectival patients rot. However, as numbers increased, it became clear that something more was required. It was then decided that a whole stationary hospital, containing 250 beds, should be allotted to this task. The choice of hospital seems to have been determined by the fact that the Commanding Officer was unpopular with his superiors. There seems no other valid reason for he knew nothing about V.D. and had no specially trained staff. Things became chaotic and the hospital became little more than a rest station before repatriation to the United Kingdom. Thus V.D. became a passport for home which was militarily unsound. So they had to call on Harrison, no doubt still reluctant but as ever determined to give of his best. He took over the hospital in January, 1915, when it contained about a thousand patients. No arsenical treatment had been given and there were still no Medical Officers in the hospital who knew anything useful about the treatment of V.D. The 
hospital was situated outside Le Havre on a site which seemed to the new C.O. the muddiest in France. Anyone who stepped off one of its few paths would be lucky to return to solid earth without losing his gumboots. So, in spite of constant changes of staff, continual admonitions from the 'high-ups' that there was a war on, and repeated curses by the General Officer Commanding Lines of Communication for keeping a hospital of this kind eating up his rations, Harrison set about bringing order out of chaos.

Members of the team at Rochester Row, which had been scattered to the four winds, were traced and posted to Le Havre. They included $\mathrm{Mr}$. Alec Winckworth, who had been a Special Treatment Orderly at Rochester Row. He is now a spry young man of 87 and has kindly given me his own recollections of the hospital at Le Havre.

Patients were accommodated in blocks of marquees. The largest was Block A dealing with cases of syphilis. 'B' dealt with non-specific lesions. The remaining sections were allotted mainly for gonorrhoea but with accommodation for dermatological cases and also for psychiatric-then called mental-cases. Huts were erected for use as treatment departments. Injections of 606 were given every afternoon from 2 to 5 p.m. by four to six Medical Officers. Colonel Harrison organized all schemes of treatment personally and supervised all activities. The numbers of admissions increased rapidly. Eventually another camp was constructed adjacent to the hospital and this was used to diminish the pressure on hospital beds. Patients with syphilis were transferred to the adjoining camp as soon as surface lesions had healed, and from there they attended for further treatment as required. Patients with gonorrhoea were able to attend daily for irrigation or other treatment. In the meantime, patients from the camp were employed on fatigues, road-making, and other activities. When patients were discharged to duty they were transferred to base camps and became reinforcements for front line and other units. Every patient recommended for discharge had to be seen and passed by Colonel Harrison. In due course a NAAFI canteen, patients' library, steam baths, a laundry, and a patients' gymnasium were added to the amenities of the hospital. These activities were conducted by patients under staff supervision. There was no resentment because those so employed received a special ration of cigarettes at the end of each day. Colonel Harrison insisted on a set formula for taking patients' histories and recording treatment, and the record had to include a description of the source of infection, including her clothing and where she was likely to be found. An R.A.M.C. officer maintained close communication with the local French Medical Officer of Health who was furnished with all these details. French police in plain clothes followed up the information and, when possible, took the women into custody for examination. So contact tracing is not such an innovation as some might think. Colonel Harrison took the closest possible interest in these activities and regularly visited all departments of the hospital.

We have been calling him Colonel Harrison, as he was known for so many years, but he was not promoted Lieutenant-Colonel until 1915. For his services during this period he was mentioned in dispatches and won the D.S.O.

By the spring of 1916 the hospital had expanded to 3,000 beds. So well were the courses of arsenical therapy designed and controlled that, in spite of the inherent dangers, there were only five deaths among 16,000 men with syphilis treated up to the end of the war.

In April, 1916, Harrison was recalled to England to take command of the Rochester Row hospital, now expanded to 300 beds, and to be Adviser in V.D. to the War Office. By this time he was able to leave his hospital in France in thoroughly competent hands. As Adviser he was appointed, in 1917, as Honorary Physician to the King and promoted to the rank of Brevet-Colonel.

Harrison has placed on record his determination to leave the Army after 20 years' service, provided that the war had ended by that time. He was then drawing the pay and allowances of a full Colonel but there were no prospects for any improvement in his financial position for many years. Furthermore, his future in the Army would involve a diminution in the practice of Medicine. He was, therefore, very interested to receive, early in 1919, an invitation to become lecturer in V.D. at Edinburgh University with charge of the V.D. Department to be established at the Edinburgh Royal Infirmary. Soon afterwards he visited Edinburgh to discuss the proposal and to see the premises in which the clinic was to be accommodated. These he found to be cramped, and altogether inconvenient. To quote his own words: ' ... from experience in the Army I had resolved that I would never run a civilian clinic in premises that were not adapted to the work. I was tired of seeing the washhouse conditions in which V.D. was expected to be treated in many military stations and indeed in a number of civilian hospitals which I had seen.' Being the forthright man he was, he informed the authorities in Edinburgh that he was not willing to take the appointment if it meant that the department was to be housed in those premises. He was assured that funds were available and this difficulty could be met and, 
later in the day, he was asked what kind of premises he wanted. At this point he had not considered this aspect of the problem in any detail and was, in fact, rather taken aback. However, he promised to prepare a plan by the following day. He at once provided himself with a small drawing board and the necessary materials for drawing a plan. When at last free from interruptions he sat down in his hotel bedroom at 11 p.m. that night and began to think over the principles which should govern such a design.

They were:

(1) Waiting periods should be kept to a minimum.

(2) Examination of patients should be conducted in the greatest possible privacy and never in the presence of other patients.

(3) There should be ease of access of staff to patients.

(4) The distances covered by staff and the time occupied in obtaining necessary instruments and drugs should be kept to a minimum.

These principles seem obvious to us now but by the standards of those days they were highly original.

In thinking about this matter he recalled that in certain personal financial crises in his student days in Glasgow his watch had to be entrusted for a time to the care of an 'avuncular relative'. Having had opportunities of studying the business premises of this same relative, it occurred to him that the principles on which they had been designed were very similar to those required for a V.D. clinic. On entering uncle's establishment he had found a passage from which a number of small cubicles opened and on the other or inner end of each cubicle was a counter at which the transaction could be arranged. No client was able to see another, but uncle was able to see them all without having to open any door.

Basing his designs on these principles, Harrison sketched a plan for a hut, 60 feet by 30 feet; he completed the work at about 3 a.m. and handed it next day to the committee conducting the negotiations. In due course his conditions were accepted and the matter was settled.

A little later he became a member of a committee presided over by Lord Astor which was appointed to decide what measures should be taken to prevent the spread of infectious disease on demobilization. The secretary of the committee drafted a report which Harrison strongly criticised. First he objected to the term 'infectious disease' when what was meant was venereal disease. (The sterile euphemism 'sexually-transmitted disease' had not yet been invented.) $\mathrm{He}$ described the report as useless because it contained nothing constructive. Having accepted the invitation to take up the post in Edinburgh, he felt that he could not be said to have a personal axe to grind. He sent in a list of suggestions which included the following:

'The Ministry of Health should have an Adviser in V.D. who is a medical officer in charge of a clinic which in design and conduct embodies certain model principles.'

To his surprise his suggestions were accepted and he was asked to put them into practice-a circumstance which perhaps indicates that those who govern us, and their advisers, are not quite so clueless as some people are apt to think. Harrison replied that he had already accepted an invitation to take charge of a V.D. clinic in Edinburgh. The Minister of Health then asked the Edinburgh authorities to release him from his undertaking and he was duly appointed the first Adviser in Venereal Diseases to the Ministry. At the same time, by arrangement between the Ministry, the London County Council, and St. Thomas's Hospital, he was invited to take charge of a V.D. clinic at the hospital operating in premises of his own design and to be open all day from 8 a.m. to 8 p.m. six days a week and on Sunday mornings.

Difficulties arose about the premises for the clinic. Harrison was offered a coal cellar and, while not refusing this, he asked also for a hut, 120 by 40 feet for the section of the clinic dealing with men. He had realized that the depressing cellar could be adapted for a clinic for females and how right he was can be seen in Fig. 2 (overleaf).

A hut suitable for his requirements was available, the so-called Hut E, but this was wanted by another member of the staff and Harrison was informed that the coal cellar, duly tiled and fitted up, would have to do for both clinics. He was not the man to accept this kind of treatment and retorted that if the committee of the hospital thought he did not know what was required he could not be regarded as a fit man for the job. The treasurer of the hospital, with whom these negotiations were conducted, promised to look into the matter again in the light of Harrison's opinion and the agreement with the London County Council, and in due course the Colonel got his way. A laboratory was fitted out at one end of the hut, in a kind of annexe. This too, led to some friction with the hospital pathologist, but Harrison had no doubt that the necessary tests, and particularly serological tests, should be carried out by a well-trained pathologist and not by a technician. Similarly, he regarded cultures of the gonococcus as a highly specialized service which should be available without restriction. In addition, he wanted the laboratory to conduct research. He was convinced that none of these needs would be fully met by existing hospital laboratories. In his laboratory two pathologists were employed full-time until the outbreak of the second world war 


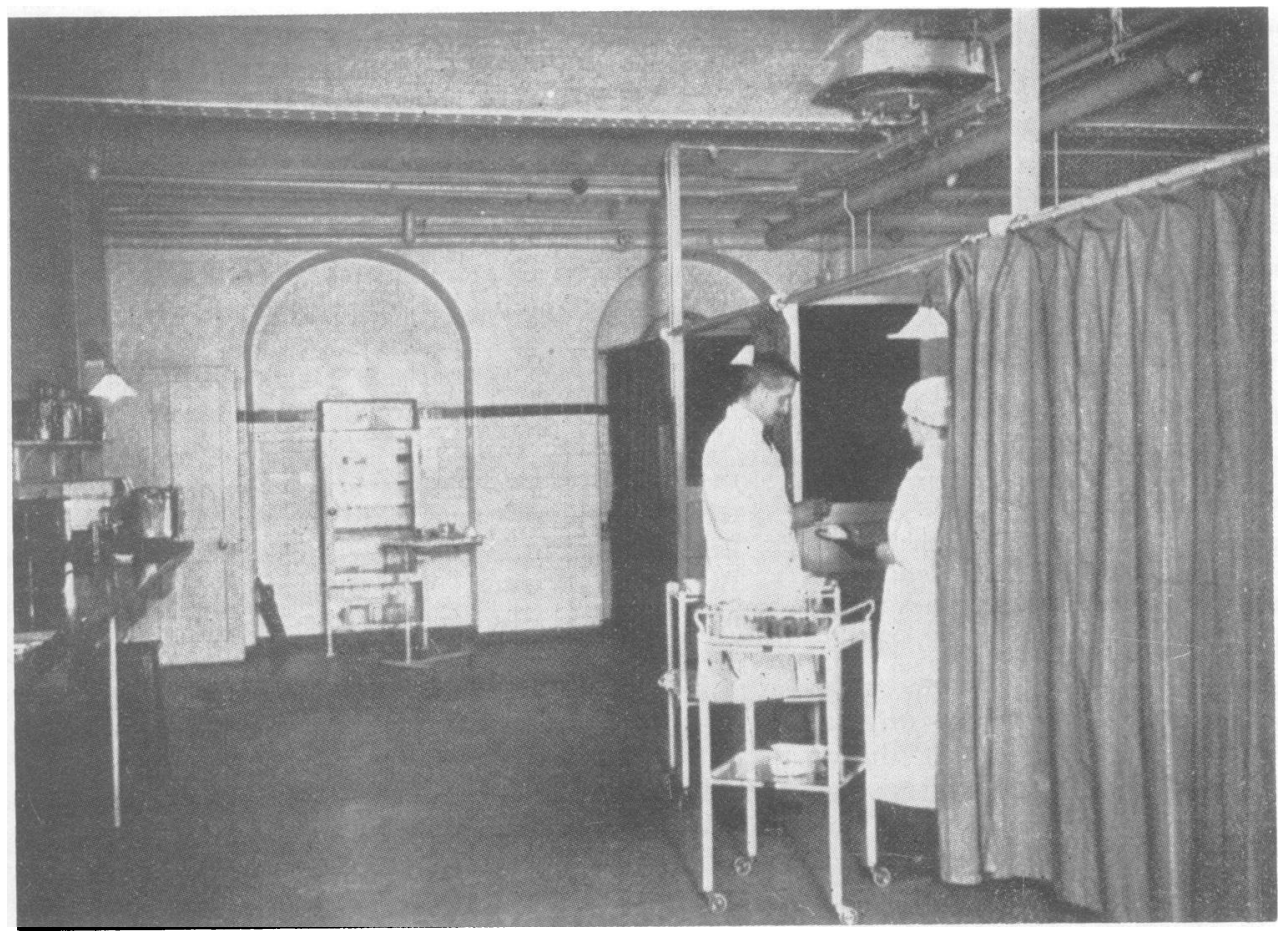

FIG. 2 Service space in section for females, St. Thomas's Hospital. Examination cubicles (one closed by curtain) on right; work bench on left

when the senior pathologist, Dr. (later Brigadier) T. E. Osmond, was appointed Adviser in V.D. to the War Office, and throughout those difficult years gave most distinguished service in organizing the venereological service of the British Army.

Harrison had no doubt that considerable benefit derived from the fact that the Ministry's adviser was a practising clinician in charge of a major clinic. He was able to visit clinics throughout England and Wales and, as he said, there was plenty of room for suggestions for improvement, suggestions which were reasonably well received because it was known that they came from practical experience. A time of financial stringency, perhaps similar to that which we now face, overtook his plans in the early 1920s when, by operation of the so-called 'Geddes axe', no money was available for the extension of V.D. or other services. With careful management he was able to save money by diminishing extravagance, and thus he set an example to others by which some extensions could go forward without further expenditure. Necessary changes had to be introduced by persuasion and not by forceful methods, and in this Harrison may have found some difficulty. Although fundamentally a kind and considerate man, his Army service had made him used to command and he was never one to suffer fools gladly. There is a hint of this in the Obituary Notice written by his former chief, Sir Arthur McNalty, who was closely associated with Harrison's work at the Ministry in early years and, in the mid 1930s, became Chief Medical Officer to the Ministry. He wrote ${ }^{2}$ : 'In the Army Harrison had been accustomed to give R.A.M.C. officers rules and directives as to diagnosis and treatment, and it took a little time for him to become accustomed to the Ministry's policy of advice and peaceful persuasion'. Sir Arthur went on to speak of his great qualities and to say that they worked together in perfect harmony.

At this point I should like to refer briefly to Harrison's plan for a V.D. clinic which was based on the principles already mentioned. ${ }^{3}$

Fig. 3 shows the lay-out of Hut E at St. Thomas's which became the prototype for so many clinics throughout the country. The problems were rather different then than now. The number of new patients was large then, as it is now, but most of them took a long time to get well and a good deal had to be sacrificed to the need for a quick turnover. Also, a considerable amount of accommodation had to be 


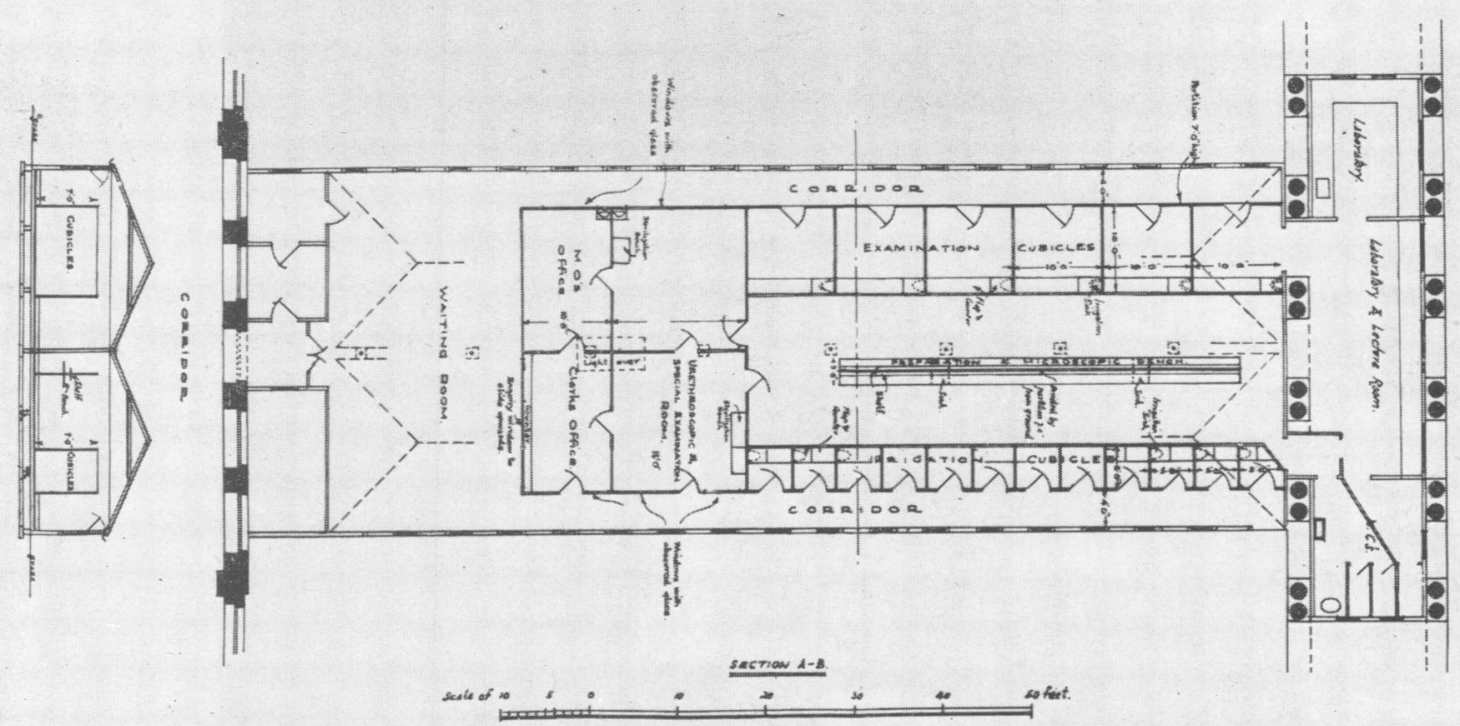

FIG. 3 Plan of St. Thomas's Hospital V.D. Department (males)

given over to prolonged urethral irrigations for men and local treatment for women. Hut $\mathrm{E}$ was far from ideal as the shell of a medical department. Gerald McElligott, Harrison's successor at the Ministry, who worked in Hut E, described $\mathrm{it}^{4}$ as: '. . . most unpromising premises in a big army hut with a tree growing through its floor and roof'. But it was skilfully designed and equipped and fulfilled its purpose admirably. The patient was able to enter from the main corridor of the hospital, thus avoiding the embarrassment of a distinctive area of approach. $\mathrm{He}$ entered the waiting room and gave details for the confidential register at the clerks' office where he received a card marked with his number. $\mathrm{He}$ was then directed to proceed along the corridor on the left, that is above in the plan, and entered one of the numbered cubicles which was named to him. Each cubicle was shut off from its neighbours and from the corridor by partitions but was open to the service space in the manner shown. The opening could be closed by a curtain at will. The patient in the cubicle could not be seen by other patients who were not allowed to enter the service space. At the same time he was quite accessible to the staff working in the service space. The doctor took the history and examined the patient in the cubicle which had all the necessary apparatus for taking specimens. If these required microscopical examination, they needed only to be taken a few feet across the service space to the bench. The doctor's time was not wasted waiting for the patient to unclothe, privacy was ensured, and no time was lost in collecting appliances for dealing with patients. Appliances other than microscopes could be moved quickly on trolleys from one cubicle to another. The director of the clinic could observe from one point a large proportion of the work in progress. The right-hand corridor contained the entrances to irrigation cubicles, to which the patients were directed when necessary. At the extreme right of the sketch is the laboratory and the lecture room.

Fig. 4 gives some idea of the cubicles and the service space.

In these days when pressures are less and staff is larger we look for more amenities, especially in the way of consulting rooms with greater privacy. But in those days this design solved many problems and was a vast improvement on anything that had gone before. Hut $\mathrm{E}$ has not survived. It was destroyed by a German bomb in 1940. But it had served its purpose.

Fig. 5 shows the Colonel with some members of his staff.

Harrison put great emphasis on the importance of teaching undergraduates and was considered to be a good teacher. He was something of a pioneer in the use of films for the purpose. He had two films, one for syphilis and one for gonorrhoea, and showed them at the rate of one reel per session with a projector which could be stopped at will, leaving the picture on the screen. Sometimes he had to deal with as many as seventy students in a class and he found the method a great help. Clinical teaching and the teaching of post- 


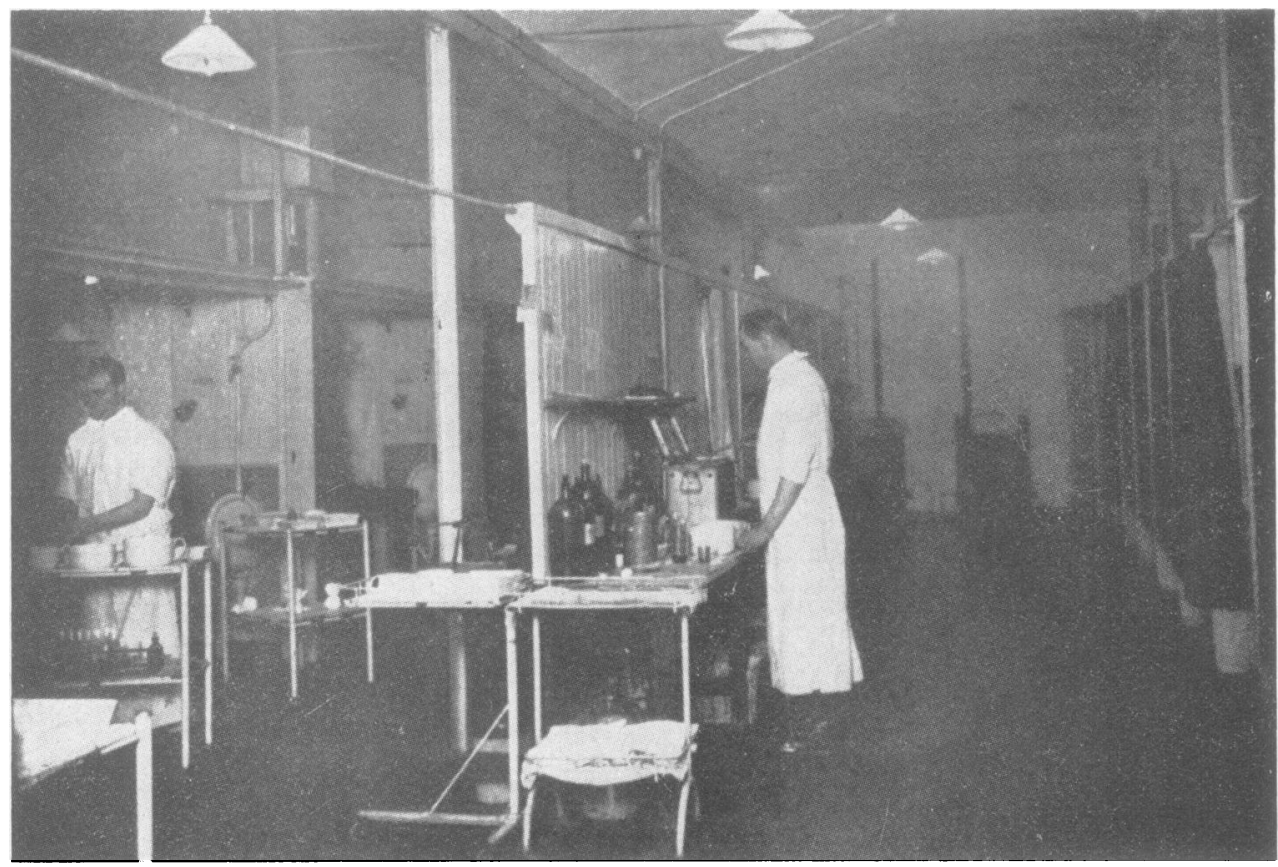

FIG. 4 Service space in section for males. Examination cubicles on left; irrigation cubicles on right; work bench in centre

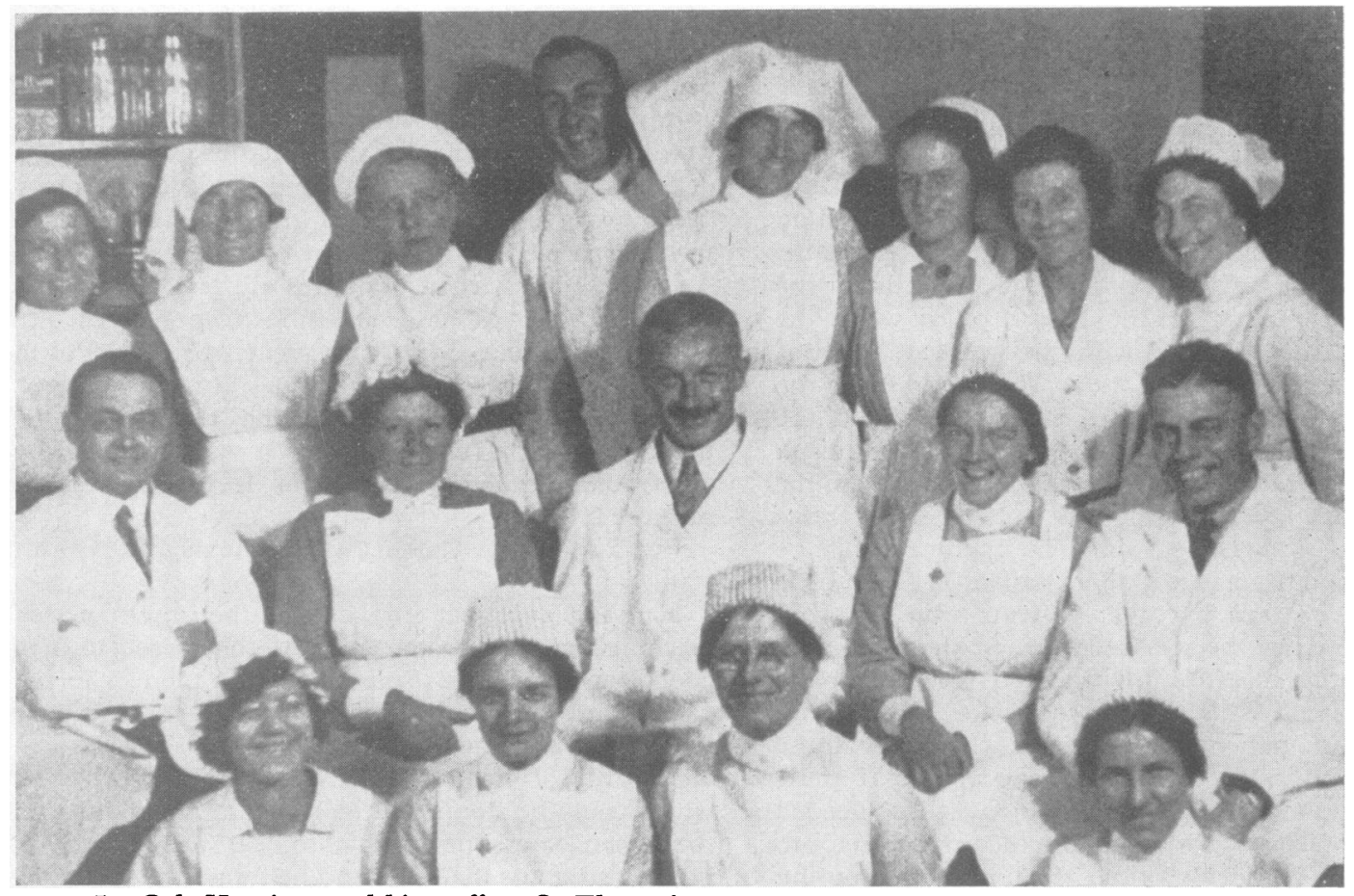

FI G. 5 Col. Harrison and his staff at St Thomas's 
graduates and nurses all received due attention.

Fig. 6 shows Colonel Harrison in his heyday and as he will be remembered by his old students and associates.

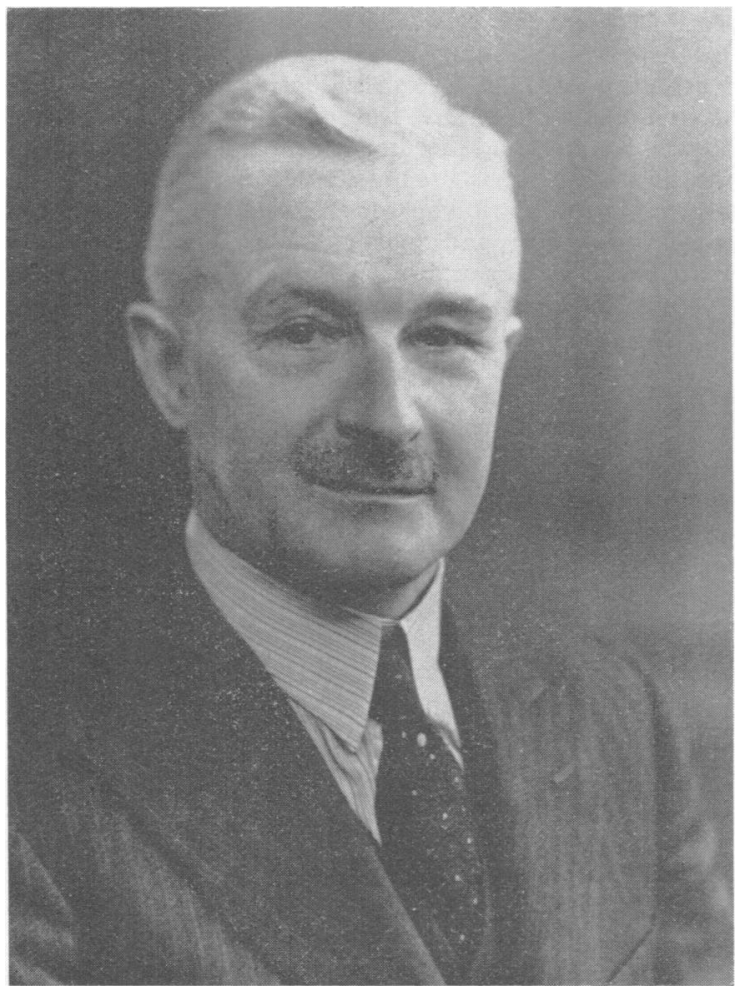

FIG. 6 Col. Harrison in middle life.

There were many activities in addition to those I have outlined. He was a founder member of this Society more than 50 years ago $^{5}$ - to be precise in June, 1922, and was President from 1923 to 1925 and again from 1938 to 1942 . With E. R. T. Clarkson of the London Hospital he was joint Editor of the British Fournal of Venereal Diseases from its inauguration in 1925 to 1939, being sole Editor from 1939 to 1942 . He contributed over 100 papers to the literature, wrote the sections on venereal disease in a number of textbooks, including Price's 'Textbook of the Practice of Medicine', and was the author of three textbooks. His 'Diagnosis and Treatment of Venereal Diseases in General Practice', which was the standard textbook for many years, was first published in 1918 and reached a fourth edition in 1931 . He published also a 'Manual of Venereal Diseases for Students' (1920) and 'Modern Diagnosis and Treatment of Syphilis, Chancroid and Gonorrhoea' (1924).

His work at St. Thomas's continued until 1936 when he retired from the staff as was customary on reaching the age of 60 . His relations with fellowmembers of the staff were probably not harmonious. He was a forthright character, rigid and unbending in the pursuit of an ideal, devoted to the care of patients, and intolerant of those who despised his subject and obstructed his efforts. Gerald McElligott, who had been one of his young men at St. Thomas's wrote about him as follows' 'I am glad, grateful, and not a little proud to have been trained in Harrison's clinic at St. Thomas's nearly 40 years ago. Though a good doctor, the Colonel was essentially a soldier. This was just as well as, in founding a new specialty, a fighter was needed. That he was not particularly popular with the honorary staff is perhaps understandable, for his department quickly acquired a national, and indeed an international, reputation and this they found difficult to understand. It was, though, to their shame that they never elected him member of their medical committee'.

His retirement from St. Thomas's was by no means the end of his activities in the subject. He had recently been appointed as Lecturer in Venereal Diseases to the Postgraduate Medical School at Hammersmith Hospital and this he continued for a number of years. $\mathrm{He}$ remained as adviser to the Ministry of Health until 1947 and was responsible for the planning and implementation of Regulation 33B during the second world war. For various reasons this Regulation failed in its primary objective, but it stimulated and encouraged a considerable surge of activity in the field of contact tracing. In addition to all his other activities, Harrison conducted a successful consulting practice in venereology and continued this for some years after final retirement from his various appointments.

It is interesting to recall that, in common with other gifted people of his generation, he was so impressed with the results of modern treatment that he thought the problem of V.D. was about to be solved. He wrote in $1949^{6}$ that 'after the increased incidence consequent on war and the aftermath of the war has been disposed of venereal diseases should become a minor public health problem and', he went on to say, 'most of the credit for it all is due to laboratory workers'. He was a great believer in laboratory experience as a guide to clinical judgment and, whether or not one is prepared to accept this view, his own career gave excellent support to this thesis.

He was elected Fellow of the Royal College of Physicians of Edinburgh in 1925 and on retirement from the Ministry of Health in 1946 was appointed C.B. In the same year he received the William Freeman Snow Award of the American Social Hygiene Association for Distinguished Services to Humanity. 
I have been in touch with many of his past associates and have received glowing tributes to him from them all. For reasons of time and space I must be selective but the following extracts are fully representative:

First, a retired nursing Sister from St. Thomas's, Miss Vera Lake, writes as follows-

\begin{abstract}
'. . . my association with the late Colonel Harrison in work at St. Thomas's Hospital, was way back in 1920 to 1928 , as a nurse in training and as assistant to sister tutor. I attended his lectures to the nursing staff and paid several visits to the department. He was an inspiring lecturer and certainly did away with any preconceived ideas we had in general on venereal disease, its incidence, and its treatment. We held him in the highest regard ... I think what impressed me most . . . was the human approach coupled with the essential discipline required. Everything possible was done to ensure an early diagnosis and encourage perseverance of the patients in their treatment. ... We were a complete self-contained unit, outpatients, maternity ward, men's and women's wards for patients requiring hospital care and treatment, our own almoner, and our own laboratory. It was wonderfully planned. . . . Everything was made as easy as possible for the attendance of patients so that it could be kept secret-long hours for the consultants up to 8 p.m., * and for the Nursing Staff 10 p.m. It was understood that we did not clear the last cubicle and finally lock up until Big Ben had struck 10 p.m. . . . within reasonable limits no patient was kept waiting for his appointment-no queues. . . The maternity ward was invaluable. It meant the possibility of the delivery of a normal child even with a late diagnosis'.
\end{abstract}

And then, a male nurse: I have already mentioned Mr. Winckworth who was with Colonel Harrison at Rochester Row and Le Havre. On leaving the R.A.M.C. in 1927, Mr. Winckworth joined the staff of the St. Thomas's clinic and later (1930) became charge nurse in the clinic for males where he continued until retirement in 1955. From his long letter I have extracted the following:

' $\mathrm{He}$ (Colonel Harrison) was a strict disciplinarian. He expected and received a high standard of efficiency from his staff. He was brief in conversation but at the same time always approachable when necessary. I enjoyed the whole period of my service under Colonel Harrison's directorship, both civil and military ... I shall always remember Colonel Harrison with pride ... I have worked with many venereologists; some have been excellent but I have never known one up to the standard of the Colonel as I knew him'.

Dr. Sidney Woodhouse, one of his Assistants at St. Thomas's for many years, wrote to me about the

*Dr. Woodhouse informs me that in fact doctors remained on duty on all weekdays up to 10 p.m. high quality of standards and organization at the clinic. He continued ...

'All the time he (Colonel Harrison) was supervising the formation of other clinics, advising on the choice of doctors, keeping a close eye on all the medical cards of his own clinic, from which he would choose for his weekly student class for exposition. He was a meticulous devourer of all literature, from home and abroad, relative to his specialty, and met his own staff for one hour every Wednesday for a discussion at an arranged tea party. . . . His application and whole-hearted devotion to his cause made him rigid and maybe obdurate in committee, perhaps unable to give ground. ... His enthusiasm for his subject made him difficult of conversation in any other sphere, and I rather doubt if he enjoyed any leisurely relaxation.'

Dr. Woodhouse goes on to describe him as a man in the Montgomery class, single-minded, altruistic, honest, industrious, and of great application. He tells us that his former chief did once take a holiday, in the Pyrenees-evidently a matter of some surprise concerning which his staff was hoping for some description at the next tea party. The only reference made to this expedition concerned the medical treatment Colonel Harrison had suggested for the wife of the landlord at the hotel where he stayed.

On the other hand, the surviving son of the house, Colonel Douglas Harrison, gives us a very different impression of his father's extramural activities. He recalls that the Colonel was very interested in wireless in the early days of broadcasting. In spite of very limited spare time, he often spent hours late into the night constructing a new wireless set, indifferently assisted by a small younger son. Fig. 7 may show just such an occasion.

He was deeply interested in gardening, particularly in the care and cultivation of roses, indulging this passion in the late 20 s and early 30 s at the holiday house in Suffolk, and after the second world war, in the Eccleston Square garden. Another hobby was motoring, and the young Harrison recalls the family driving out into the country, first on a motor-cycle combination and then in cars, of which the first and most exotic was a six cylinder Speed Twenty Alvis, so low on the ground that it was constantly grounding. At one time angling was a passing interest and he became rather a menace to the rest of the family when practising casting. He often showed remarkable and unexpected knowledge of the fortunes of cricket and football teams and his family marvelled that he could find the time to keep track of such information. Because he worked so hard he seemed a little remote to the junior members of his family. He saw little of them except at meals. Breakfast was punctually at 8.15 on weekdays and 9 a.m. on Sundays. Dinner at 


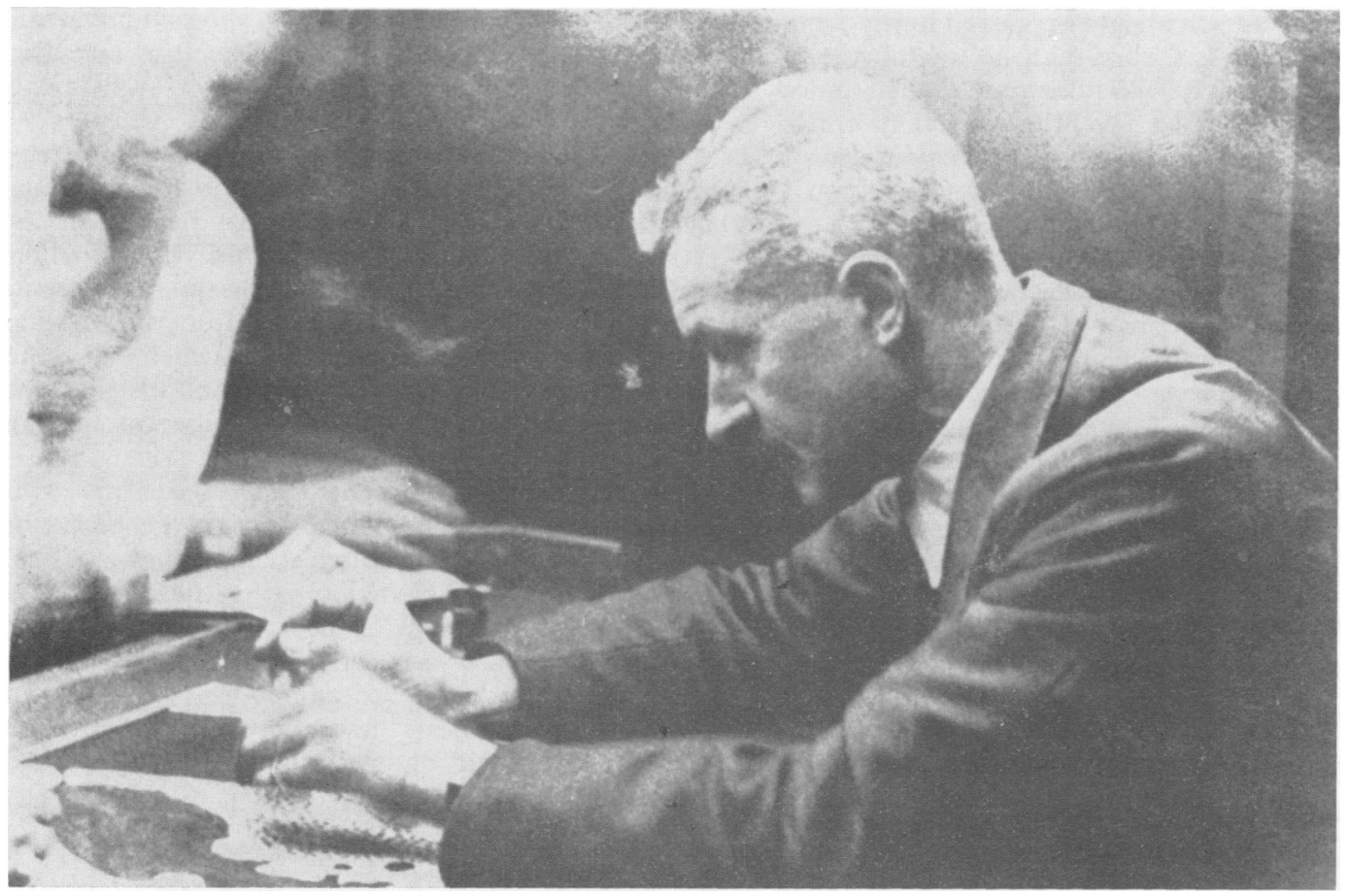

FIG. 7 Col. Harrison at home in pursuit of a hobby

8 p.m. was a formal occasion by today's standards. The Colonel always wore a dinner jacket. He soon withdrew to the 'consulting room' downstairs for some writing. He was exceptionally self-disciplined and believed that people should learn to stand on their own feet. Nevertheless, he was a kind man, as his son, when a hard-up subaltern, and other members of the family, had good reason to know.

Returning for the moment to Gerald McElligott ${ }^{4}$, he described his old chief as an honourable, hardworking, shrewd north-country man, full of dry humour and a kindliness which he did his best, quite unsuccessfully, to conceal. Though he despised and was quick to recognize frauds, he had only one hatred, injustice, and he instinctively fought hard for anyone he thought was getting a rough deal. When he detected unfairness in any guise, he was liable to see red and was not particular what he said to those he thought responsible. This did not make for popularity in some quarters, but he was universally respected and in time his great qualities were appreciated by all those whose opinions really mattered.

Sir George Godber, until very recently Chief Medical Officer of the Department of Health and Social Security, who knew him well, was kind enough to give me a personal assessment:

'I remember being taught by him in that old hut which is described as the model clinic, close to 40 years ago. . . . As I recall him he was a good teacher, if a little didactic. $\mathrm{He}$ was always ready to discuss why, rather than to assume that his own authoritative pronouncement was final. . . . He taught at the London School of Hygiene when I was doing the D.P.H. there. . . . When I came to know him in the Department I found him always cogent on paper but sometimes a little hesitant in oral exposition. $\mathrm{He}$ had, of course, an unequalled store of information. .. . What I shall specially recall about Harrison in the office was his unfailing courtesy and sometimes almost diffidence in putting his view forward. Of course, he could be explosive but he got on extraordinarily well with Sir Wilson Jameson and, of course, greatly influenced the action taken during the war.' (Sir Wilson Jameson was, of course, Chief Medical Officer at the Ministry during the second world war and for some time after it.) Sir George continues: 'Looking back close to 30 years he remains with me as one of the most impressive colleagues of my 35 years here. ... We surely owe a tremendous amount to him in this country.'

After this it will seem something of an anticlimax for me to record some of my own impressions of this considerable man. I have always regretted that I had not the good fortune to work in his department. I first began to feel his impact when I joined this society in 1930 and started to attend the meetings. His was a formidable personality. He was obviously 
the big shot; he knew it all and expressed himself in a forthright manner. As I have said, he was unable to suffer fools gladly but he was tolerant of the ignorance and stupidity of the young. Over the years, in meetings of the council of the society and in a variety of ways I came to know him well. It was by his agency that I became a member of the executive committee of the International Union against the Venereal Diseases and I have the happiest recollections, in post-war years, of attending meetings of the committee with him in Paris and Rotterdam. He was a most pleasant companion, far from austere, with an interesting mind and a fund of information on many matters other than his own subject. He strove, with some minor assistance on my part, to break the stranglehold in which some officials of long-standing held the International Union for a number of years and which was stultifying its activities-and how he loved the battle! When that stranglehold was at last broken, he had retired from the executive committee but he had laid the foundations of ultimate success.

Fig. 8 was sent to me by Dr. Robert Forgan, the senior member of this Society and the last surviving contemporary of the Colonel. It shows him at an international meeting with Mrs. Harrison and Dr. Forgan. We are not sure of the date or even of the country.

Colonel Harrison, more than anyone, was instrumental in bringing into being the British Federation against the Venereal Diseases which remains as an active organization. His interest and determination remained to the end. After I had become Adviser to the Ministry he would telephone me from time to time to tell of some neglect or irregularity which had come to his notice, perhaps at some small and insignificant clinic. His zeal for the cause of patients and the efficiency of the service never left him.

Perhaps, finally, I might read to you my own contribution to his Obituary Notice in the Lancet of May $16,1964^{7}$. It was written in complete sincerity:

'Harrison gave his life to improving the standards of diagnosis and treatment of the venereal diseases and, by education, not least of his own profession, to changing the popular attitude to this vast human problem. Few pioneers have chosen a more difficult field for endeavour, and few who achieved so much

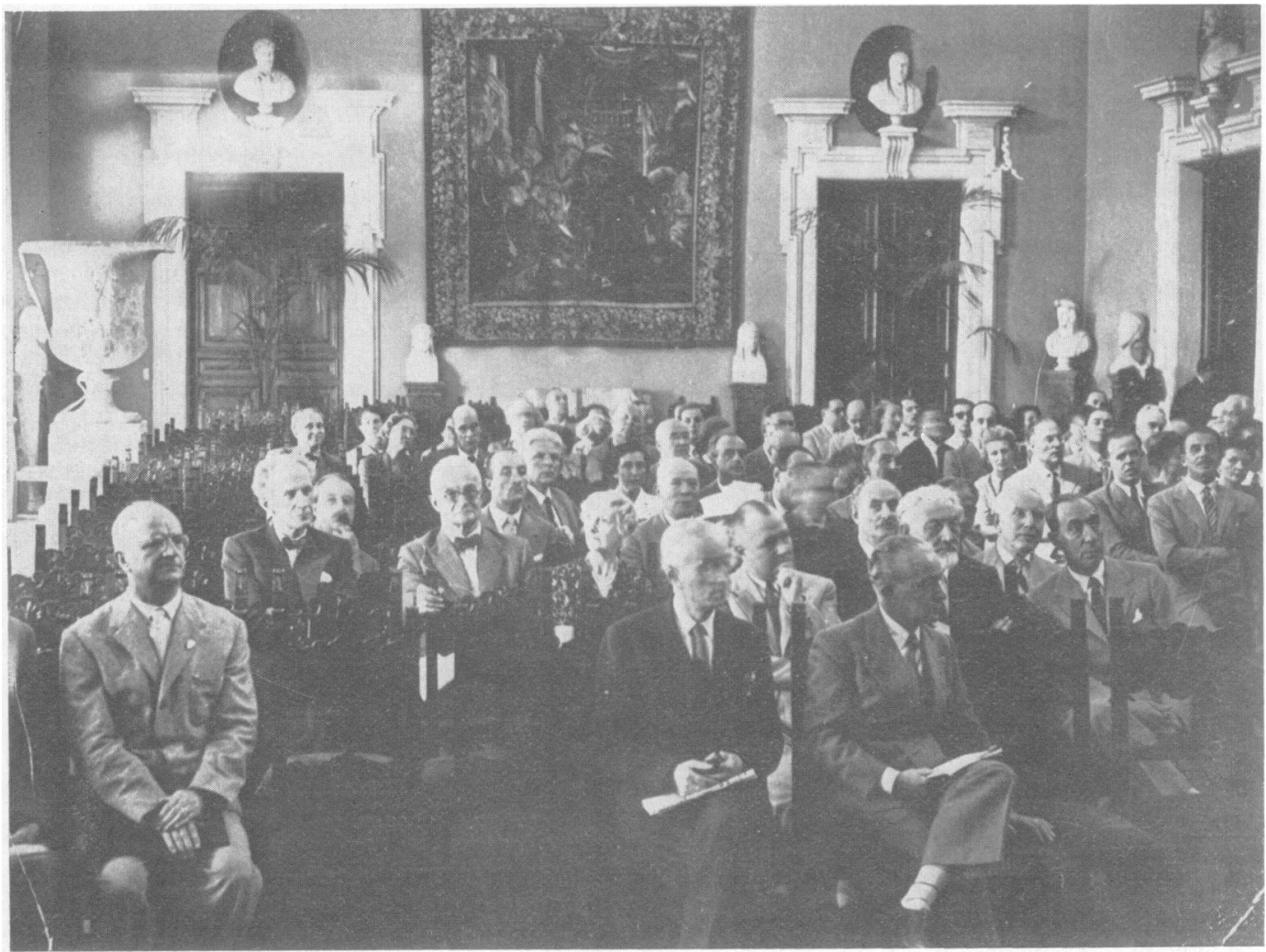

FIG. 8 Col. Harrison with his wife and Dr Forgan at a medical meeting abroad 
have gained so little general recognition. He devoted himself to a despised and neglected subject which most of his contemporaries regarded with considerable distaste, and to the welfare of sufferers whom most people, in and out of the Services, regarded as worthy of punishment rather than of medical care. To this he brought clinical acumen, painstaking attention to detail, absolute honesty and integrity, exceptional courage and persistence, and a flair for administration. After retirement he continued to act as the elder statesman of his specialty. He took a most active interest in the welfare of the devoted band of male nurses who had played so large a part in raising and maintaining the efficiency of V.D. clinics, and he was for some years president and examiner to the Institute of V.D. Technicians. He will be remembered with the utmost affection and respect by all who have worked in the subject in the United Kingdom during the past 40 years and by a host of admirers abroad. His last years were clouded by illness but the vigour of his mind never waned. His death ends a long life of remarkable achievement.'

This, then, Mr. President, Ladies, and Gentlemen, is the story. There must be many gaps because so many of the Colonel's immediate colleagues are dead; but those who survive have been very kind and helpful. The story contains no glamour, no violence, and no sex, in the sense in which the word is understood in the entertainment business. But it is the story of an idealist with remarkable qualities from which we can all learn. Colonel Harrison would have hated a eulogy and I suppose this is one. My one regret is that he will not be on the telephone to-morrow morning to tell me exactly what he thinks of it and of me.

I should like to acknowledge the kindness of many people who have helped me with information, photographs, and documents. They include Mrs. M. A. Harrison, Colonel Douglas Harrison, Sir George Godber, Dr. C. S. Nicol, Mrs. Frances Clements, Colonel Basil Levy, Major-General T. W. Carrick of the Royal Army Medical College, Dr. Sidney Woodhouse, Dr. Robert Forgan, Brigadier T. E. Osmond, Miss Vera Lake, Mr. Alec Winckworth, and the Superintendent of the British Library (Reference Division).

\section{References}

1. Harrison, L. W. (1949a) Med. illus., 3, 318

2. MCNalty, A. (1964) Lancet, 1, 1113

3. HaRRISON, L. W. (1922-23) St. Thomas's Hosp. Gaz, 29, 217, 266

4. McElligott, G. (1964) Brit. F. vener. Dis., 40, 228

5. HARRISON, L. W. (1961) Ibid., 37, 2

6. - (1949b) Med. illus., 3, 376

7. KING, A. J. (1964) Lancet, 1, 1113 